\title{
Peningkatan Proses Pembelajaran Pendidikan Agama Islam Melalui Penerapan Model Kooperatif Tipe Jigsaw dengan Menggunakan Media Video Zakir Naik
}

\author{
Salamah \\ Sekolah Tinggi Ilmu Ekonomi Sakti Alam Kerinci \\ Amah0473@gmail.com
}

\begin{abstract}
Islamic education faces several problems and challenges, one of the problems is that the portion of PAI hours at STIE Sakti Alam Kerinci is relatively small, which is 2 credits, so that it impacts on methodological problems, the learning strategy takes the form of lectures, because it is considered effective in overcoming time constraints i.e. lecturers explain while students hear and take notes. Not infrequently when given the opportunity to ask, not a student raised his hand to ask. This condition causes the class to be less dynamic and pleasant. This study aims to improve the process and results of Islamic Education using a cooperative type jigsaw model through video media Dr. Zakir Naik on STIE Sakti Alam Kerinci accounting study students. The population in this study were Accounting students in the even semester of the 2017/2018 academic year, totaling 90 people. In this study the author took only Accounting Class I which amounted to 45 people. Data collection is obtained through observation, interviews with students and documentation. The increase in the implementation of the Islamic Religious Education learning process using the jigsaw cooperative model through Zakir Naik's media in the first cycle, the second cycle and the third cycle became more enjoyable than before because students had new experiences, students who were less active became active during learning, student antusui seen when discussing.
\end{abstract}

Keywords: Increased learning process, jigsaw, cooperative learning

Abstrak: Pendidikan Agama Islam menghadapi beberapa problem dan tantangan, salah satu masalahnya yaitu porsi jam PAI di STIE 
Sakti Alam Kerinci relatif sedikit, yakni 2 sks, sehingga berdampak pada problem metodologis, strategi pembelajarannya pun mengambil bentuk ceramah, sebab dipandang efektif dalam mengatasi keterbatasan waktu yaitu dosen menerangkan sementara mahasiswa mendengar dan mencatat. Tidak jarang bila diberi kesempatan bertanya, tak seorang mahasiswa pun mengacungkan tangan untuk bertanya. Kondisi ini menyebabkan kelas kurang dinamis dan menyenangkan. Penelitian ini bertujuan untuk meningkatkan proses dan hasil Pendidikan Agama Islam menggunakan model kooperatif tipe jigsaw melalui media vidio Dr Zakir Naik pada mahasiswa prodi akuntansi STIE Sakti Alam Kerinci. Populasi dalam penelitian ini adalah mahasiswa Akuntasi semester genap tahun ajaran 2017/2018 yang berjumlah 90 orang. Dalam penelitian ini penulis pengambil hanya kelas Akuntansi I yang berjumlah 45 orang. Pengumpulan data diperoleh melalui observasi, wawancara dengan mahasiswa dan dokumentasi. Peningkatan pelaksanaan proses pembelajaran Pendidikan Agama Islam menggunakan model kooperatif tipe jigsaw melalui media vidio dr Zakir Naik pada siklus I, siklus II dan siklus III menjadi lebih menyenangkan dari sebelumnya karena mahasiswa mendapatkan pengalaman baru, mahasiswa yang dulu kurang aktif menjadi aktif selama pembelajaran, antusuias mahasiswa terlihat ketika berdiskusi.

Kata kunci : Peningkatan proses pembalajaran, jigsaw, pembelajaran kooperatif

\section{Pendahuluan}

Dalam kurikulum pendidikan tinggi Indonesia, Pendidikan Agama dikelompokkan ke dalam kelompok Mata Kuliah Pengembangan Kepribadian (MPK). Pendidkan Agama merupakan pendidikan nilai untuk membentuk dan membangun karakter yang berorientasi pada pembentukan dan pembinaan kepribadian mahasiswa sebagai warga negara Indonesia yang beriman dan bertakwa kepada kepada Allah SWT, memiliki komitmen yang tinggi pada nilainilai kemanusiaan. Untuk membentuk dan membangun karakter mahasiswa yang memiliki komitmen yang tinngi pada nilai-nilai kemanusiaan, posisi Pendidikan Agama di PTU dari semua jenjang dan jenis pendidikan, baik secara historis maupun secara konstitusional telah menjadi kebutuhan semua pihak. 
Hal itu terlihat dari diakuinya agama dalam berbagai kebijakan nasional, seperti sila pertama Pancasila, yakni Ketuhanan Yang Maha Esa; UUD pasal 29 ayat 1 dan 2 yang berbunyi: (1) negara berdasarkan atas Ketuhanan Yang Maha Esa. (2) negara menjamin kemerdekaan tiap-tiap penduduk untuk memeluk agamanya masing-masing dan untuk beribadat menurut agamanya dan kepercayaanya itu.

Selain itu, Undang-Undang Sisdiknas 2003 Bab II pasal 3 tentang fungsi dan tujuan pendidikan menyebutkan bahwa pendidikan nasional berfungsi mengembangkan kemampuan dan membentuk watak serta peradaban bangsa yang bermartabat dalam rangka mencerdaskan kehidupan bangsa, bertujuan untuk berkembangnya potensi peserta didik agar menjadi manusia yang beriman dan bertakwa kepada Tuhan Yang Maha Esa, berakhlak Mulia, sehat, berilmu, cakap, kreatif, mandiri, dan menjadi warga negara yang demokratis seta bertanggung jawab. Bab $\mathrm{V}$ pasal 12 ayat 1 tentang hak peserta didik untuk memperoleh pendidikan agama sesuai dengan agama yang dianutnya dan diajarkan oleh pendidikan yang seagama.1 Atas itu semua, PAI merupakan bidang studi yang wajib di ajarkan mulai dari tingkat Taman Kanak-kanak (TK) hingga Perguran Tinggi (PT). Maka disusunlah visi dan misi Pendidikan Agama Islam di PTU yaitu berkembangnya mahasiswa sebagai manusia terpelajar yang kritis, peka dan arif dalam memahami keragaman, kesederajatan manusia yang dilandasi nilai-nilai estetika dan moral dalam kehidupan masyarakat. Sedangkan misi PAI di PTU adalah memberikan landasan dan ajaran yang luas serta menumbuhkan sikap kritis, peka dan arif pada mahasiswa untuk memahami keragaman dan kesederajatan manusia dalam kehidupan masyarakat selaku individu dan makhluk sosial yang beradap dan bertanggung jawab terhadap sumber daya manusia dan lingkungannya. Adapun tujuan PAI di PTU sebagi berikut: $^{2}$

1. Mengembangkan kesadaran mahasiswa menguasai pengertian tentang keanekaragaman dan kesederajatan manusia sebagai individu dan makhluk sosial dalam kehidupan masyarakat yang diwarnai oleh ajaran agama.

2. Menumbuhkan sikap kritis, peka dan arif dalam memahami keberagaman dan kesederhanaan dengan landasan nilai estetika, etika dan moral yang memiliki rasa agama dalam kehidupan masyarakat.

\footnotetext{
1 Abd. Rahman Assegaf, Studi Islam Kontektual Elaborasi Paradigma Baru Muslim Kaffah, (Yogyakarta: Gama Media, 2005), hal. 1

2 Azyumardi Azra., dkk, Buku Teks Pendidikan Agama Islam Pada Perguruan Tinggi Umum,(Jakarta: Derektorat Perguruan Tinggi Agama Islam, 2002), hal. 1
} 
3. Memberikan landasan pengetahuan dan wawasan yang luas serta keyakinan kepada mahasiswa sebagai bekal bagi hidup bermasyarakat, selaku individu dan makhluk sosial yang beradab mempraktekkan pengetahuan akademik dan keahlian dengan landasan nilai-nilai agama.

Untuk mewujudkan tujuan diatas ada empat dimensi pokok yang harus diperhatikan dalam proses pembelajaran PAI di kelas, yaitu :

1. Dimensi keimanan mahasiswa terhadap ajaran Agama Islam.

2. Dimensi pemahaman (intelektual) serta keilmuan mahasiswa terhadap ajaran agama Islam.

3. Dimensi penghayatan atau pengamalan batin yang dirasakan mahasiswa dalam mejalankan syariat Agama Islam.

4. Dimensi pengalaman dalam arti bagaimana ajaran Agama Islam yang telah diyakini dan diimani itu dapat dipahami dan dihayati oleh mahasiswa kemudian mampu diamalkan dalam kehidupan sehari-hari.

Berdasarkan observasi dilapangan pembelajaran PAI di STIE SAKTI Alam Kerinci mengahadapi berbagai problema sekaligus tantangan yang perlu segera dicari jalan keluarnya. Beberapa problem dan tantangan tersebut meliputi: pertama, porsi jam PAI di STIE Sakti Alam Kerinci relatif sedikit, yakni 2 sks. Jadi seorang mahasiswa yang menempuh kuliah di STIE Sakti Alam Kerinci jenjang S-1 selama 4 tahu, ia akan menerima mata kuliah PAI hanya satu semester atau maksimal 16 kali tatap muka. Selebihnya, hingga mahasiswa tersebut lulus dan wisuda, ia tidak bertemu lagi dengan mata kuliah PAI. Disamping itu materi PAI merupakan gabungan yang memuat berbagai bidang PAI. Bidang ibadah-syariah, akidah-akhlak, tafsir-hadis, sejarah kebudayaan Islam, serta bidang lainnya yang juga sudah menjadi disiplin ilmu sendiri, dalam PAI di STIE Sakti Alam Kerinci dicangkup menjadi satu.

Kedua, padatnya materi PAI dan sedikitnya waktu yang tersedia, mengakibatkan dosen kewalahan dalam mengejar target kurikulum yang harus disampaikan kepada mahasiswa dalam satu semester, sehingga pelajaran cenderung menjadi bersifat normatif dan kurang aplikatif. Ketiga, problem metodologis, strategi pembelajaran PAI yang selama ini ditempuh oleh para pendidik masih mengandalkan metode konvensional, seperti ceramah, tanya jawab atau tugas terstruktur. Jalur komunikasi yang terbentuk akibat strategi tersebut umumnya bersifat satu arah atau dua arah, yaitu dosen menerangkan sementara mahasiswa mendengar dan mencatat. Tidak jarang bila diberi 
kesempatan bertanya, tak seorang mahasiswa pun mengacungkan tangan untuk bertanya. Kondisi ini menyebabkan kelas kurang dinamis dan menyenangkan.

Berdasarkan masalah-masalah tersebut dan refleksi diri, maka penulis tertarik untuk melakukan perbaikan dengan merubah pendekatan dengan menggunakan media pembelajaran, yang dikemas melalui penelitian tindakan kelas dengan judul "Peningkatan Proses Pembelajaran Pendidikan Agama Islam Melalui Penerapan Model Kooperatif Tipe Jigsaw Dengan Menggunakan Media video dr. Zakir naik di Kelas Akuntasi STIE Sakti Alam Kerinci Sungai Penuh Semester Genap Tahun 2017/2018”

Hasil dari kajian tersebut secara garis besar, indikator yang ingin dicapai dalam penelitian ini adalah meningkatnya kualitas pembelajaran serta pemahaman mahasiswa prodi Akuntansi STIE Sakti Alam Kerinci semester genap tahun ajaran 2017/2018. Untuk mengetahui peningkatan tersebut, digunakan indikator sebagai berikut.

1. Kualitas proses pembelajaran PAI dalam materi hakikat Agama, ditandai dengan:

2. Keaktifan mahasiswa dalam pembelajaran baik aktif bertanya maupun memberikan tanggapan, aktif mengerjakan tugas serta menjawab pertanyaan dosen;

3. Perhatian serta konsentrasi mahasiswa terhadap pembelajaran;

4. Minat serta motivasi mahasiswa untuk mengikuti pembelajaran;

5. Dosen mampu mengelola kelas dengan baik.

Untuk mengetahui peningkatan kualitas pembelajaran PAI dalam materi hakikat Agama, peneliti mengamati pembelajaran yang berlangsung menggunakan pedoman observasi.

Kemampuan memahami hakikat agama, ditandai dengan penampilan mahasiswa dalam diskusi dan kemampuan menjawab soal.

Adapun yang menjadi prosedur pada penelitian ini merupakan rangkaian tahapan penelitian dari awal hingga akhir penelitian. Penelitian ini adalah proses pengkajian sistem berdaur sebagaimana kerangka berpikir. Prosedur dalam Penelitian Tindakan Kelas ini mencakup langkah-langkah: (1) persiapan, (2) studi/survei awal, (3) pelaksanaan siklus, dan (4) penyusunan laporan. Pelaksanaan siklus meliputi a) perencanaan tindakan (planning), (b) pelaksanaan tindakan (acting), (c) pengamatan (observing), (d) refleksi (reflecting). Banyaknya siklus yang telah dilaksanakan ada dua mengingat dalam 
penelitian tindakan ini, pada siklus terakhir (siklus II) telah mencapai indikator kinerja atau capaian yang telah ditetapkan.

Selanjutnya hasil penelitian tentang pelaksanaan peningkatan proses pembelajaran Pendidikan Agama Islam melaui penerapan model kooperatif tipe jigsaw dengan menggunakan media vidio dr zakir naik di prodi Akuntansi STIE Sakti Alam Kerinci Semester Genap Tahun Ajaran 2017/2018, dilakukan dalam tiga siklus. Berikut ini akan dideskripsikan hasil penelitian tindakan kelas menggunakan model kooperatif tipe jigsaw (prasiklus) pada siklus I, siklus II dan siklus III. Deskripsi Peningkatan Pelaksanaan Proses Pembelajaran Pendidikan Agama IslamMelalui Penerapan Model Kooperatif Tipe Jigsaw dengan Menggunakan Media Vidio dr Zakir Naik di Prodi Akuntansi STIE Sakti Alam Kerinci Semester Genap Tahun Ajaran 2017/2018. Peningkatan pelaksanaan proses pembelajaran Pendidikan Agama Islam melalui penerapan model kooperatif tipe jigsaw dengan menggunakan media vidio dr Zakir Naik dapat meningkatkan keaktifan belajar mahasiswa. Keaktifan mahasiswa dapat dilihat dari banyaknya mahasiswa yang bertanya apabila kurang memahami penjelasan dosen. Begitu pula dengan mahasiswa atau kelompok yang semula masih malu untuk berduskusi baik dalam kelompok asal maupun kelompok ahli. Selain itu, mahasiswa yang cenderung pendiam dan tidak aktif dalam kegiatan pembelajaran yang disebabkan oleh model dosen yang kurang mampu mengaktifkan mahasiswa, kini setelah dosen menerapkan model kooperatif tipe jigsaw dengan menggunakan media vidio dr Zakir Naik mahasiswa menjadi mempunyai minat dan motivasi untuk belajar serta keberanian mahasiswa untuk berdiskusi tanpa ada rasa takut mulai terlihat banyak dibandingkan sebelum menggunakan model tersebut.

Pemahaman mata kuliah Pendidikan Agama Islam menlalui penerapan model kooperatif tipe jigsaw dengan menggunakan media vidio dr Zakir Naik dilakukan untuk memberikan variasi dalam pembelajaran, sehingga mahasiswa merasa tidak takut untuk berdiskusi baik dikelompok asal maupun kelompok ahli. Selain itu, mahasiswa juga tidak merasa bosan di dalam kelas terutama dalam proses belajar mengajar. Pelaksanaan pembelajaran Pendidikan Agama Islam dilakukan dalam dua tindakan yaitu prasiklus dan siklus. Prasiklus adalah tindakan sebelum menerapkan model kooperatif tipe jigsaw dengan menggunakan media vidio dr Zakir Naik, sedangkan Pada siklus I, II dan III, pembelajaran melaui penerapan model kooperatif tipe jigsaw dengan menggunakan media vidio dr Zakir Naik dan audio visual. Subjek yang diambil 
dari penelitian tindakan kelas ini sebanyak 45 mahasiswa pada prasiklus, siklus I, siklus II dan siklus III mahasiswa kelas Akuntansi 1 STIE Sakti Alam Kerinci.

\section{Prasiklus}

Sebelum peneliti membahas pada penelitian peningkatan pembelajaran Pendidikan Agama Islam melalui penerapan model kooperatif tipe jigsaw dengan menggunakan media vidio dr Zakir Naik, akan dibahas terlebih dahulu mengenai pelaksanaan pembelajaran PAI sebelum penerapan model kooperatif tipe jigsaw dengan menggunakan media vidio dr Zakir Naik. Untuk melihat peningkatan penerapan model kooperatif tipe jigsaw dengan menggunakan media vidio dr Zakir Naik pada pembelajaran PAI dalam materi hakikat Agama, perlu diuraikan pembelajaran sebelum menerapkan model kooperatif tipe jigsaw dengan menggunakan media vidio dr Zakir Naik. Proses pembelajaran Pendidikan Agama Islampada saat prasiklus terlebih dahulu akan dideskrispsikan sebagai berikut.

Selain kurangnya minat mahasiswa, faktor lain yang menjadi masalah dalam pembelajaran Pendidikan Agama Islamadalah model mengajar dosen yang kurang menarik perhatian mahasiswa. Pada pembelajaran Pendidikan Agama Islamsebelum menerapkan model kooperatif tipe jigsaw dengan menggunakan media vidio dr Zakir Naik, dosen hanya melalui model ceramah dan penugasan atau diskusi.

Hasil pengamatan pada saat pembelajaran menulis sebelum menerapkan model kooperatif tipe jigsaw dengan menggunakan media vidio dr Zakir Naik tercantum pada tabel berikut. Hasil Pengamatan Aktivitas Mahasiswa dan Dosen dalam Meningkatkan Pembelajaran Pendidikan Agama Islam Sebelum Menerapkan model kooperatif tipe jigsaw dengan menggunakan media vidio dr Zakir Naik Prasiklus

\begin{tabular}{|l|l|}
\hline $\begin{array}{l}\text { Jenis } \\
\text { Permasalahan }\end{array}$ & Hasil Pengamatan \\
\hline $\begin{array}{l}\text { Aktivitas } \\
\text { belajar } \\
\text { mahasiswa }\end{array}$ & $\begin{array}{l}\text { Aktivitas belajar mahasiswa kurang baik, hal ini terlihat } \\
\text { dari respon mahasiswa dalam penerimaan materi, } \\
\text { mahasiswa belum bisa konsentrasi dalam penerima } \\
\text { pelajaran, dan dosen harus sering memberikan motivasi. }\end{array}$ \\
\hline $\begin{array}{l}\text { Aktivitas dari } \\
\text { dosen }\end{array}$ & $\begin{array}{l}\text { Dosen dalam memberikan materi Pendidikan Agama } \\
\text { Islamkurang maksimal dikarenakan banyak waktu yang }\end{array}$ \\
\hline
\end{tabular}




\begin{tabular}{|l|l|}
\hline & $\begin{array}{l}\text { tersita untuk mengkondisikan mahasiswa-mahasiswa yang } \\
\text { ramai sendiri dan memotivasi mahasiswa. }\end{array}$ \\
\hline $\begin{array}{l}\text { Disiplin } \\
\text { mahasiswa }\end{array}$ & $\begin{array}{l}\text { Kedisiplinan mahasiswa masih belum maksimal. } \\
\text { Mahasiswa belum dapat menciptakan suasana } \\
\text { pembelajaran yang kondusif, meskipun bersemangat, } \\
\text { namun masih ada mahasiswa yang gaduh dan berbicara } \\
\text { sendiri dengan temannya. Selain itu, ada juga yang masih } \\
\text { keluar masuk kelas. }\end{array}$ \\
\hline $\begin{array}{l}\text { Keaktifan dan } \\
\text { percaya diri } \\
\text { mahasiswa }\end{array}$ & $\begin{array}{l}\text { Keaktifan dan percaya diri mahasiswa masih kurang } \\
\text { tampak, hal ini terlihat karena hanya sedikit mahasiswa } \\
\text { yang berani dan percaya diri mengajukan pertanyaan saat } \\
\text { pembelajaran. }\end{array}$ \\
\hline
\end{tabular}

Selanjutnya Hasil Pengamatan Penelitian Tindakan Kelas Prasiklus Dosen dan Mahasiswa

\begin{tabular}{|l|l|}
\hline Dosen & Mahasiswa \\
\hline $\begin{array}{l}\text { Kegiatan awal: } \\
\text { Dosen } \\
\text { membuka }\end{array}$ & $\begin{array}{l}\text { Kegiatan awal: } \\
\text { Mahasiswa menjawab salam dan menjelaskan kehadiran } \\
\text { mahasiswa . }\end{array}$ \\
\hline $\begin{array}{l}\text { Dosen } \\
\text { melakukan } \\
\text { apersepsi }\end{array}$ & $\begin{array}{l}\text { Sebagian mahasiswa mendengarkan tetapi ada yang } \\
\text { berbicara sendiri }\end{array}$ \\
\hline $\begin{array}{l}\text { Kegiatan inti: } \\
\text { Dosen } \\
\text { menjelaskan } \\
\text { materi } \\
\text { Pendidikan } \\
\text { Agama } \\
\begin{array}{l}\text { Islammelakukan } \\
\text { sesuatu }\end{array}\end{array}$ & $\begin{array}{l}\text { Kegiatan inti: } \\
\text { Sebagian mahasiswa mendengarkan penjelasan dosen. }\end{array}$ \\
\hline $\begin{array}{l}\text { Dosen } \\
\text { memberikan } \\
\text { kesempatan } \\
\text { mahasiswa }\end{array}$ & $\begin{array}{l}\text { Sebagian besar mahasiswa hanya diam dan hanya satu dua } \\
\text { mahasiswa yang berani bertanya. }\end{array}$ \\
\hline
\end{tabular}




\begin{tabular}{|c|c|}
\hline $\begin{array}{l}\text { untuk bertanya } \\
\text { pada materi } \\
\text { yang sudah } \\
\text { diberikan. }\end{array}$ & \\
\hline $\begin{array}{l}\text { Dosen meminta } \\
\text { mahasiswa } \\
\text { untuk mencari } \\
\text { macam-macam } \\
\text { agama, unsur- } \\
\text { unsur yang ada } \\
\text { dalam agama, } \\
\text { ciri-ciri, } \\
\text { ajarannya. }\end{array}$ & $\begin{array}{l}\text { Mahasiswa mencari macam-macam agama, unsur-unsur } \\
\text { yang ada dalam agama, ciri-ciri, ajarannya. }\end{array}$ \\
\hline $\begin{array}{l}\text { Dosen memberi } \\
\text { arahan sambil } \\
\text { berkeliling di } \\
\text { dalam kelas }\end{array}$ & Mahasiswa mendengarkan arahan dosen \\
\hline $\begin{array}{l}\text { Dosen } \\
\text { memberikan } 5 \\
\text { soal tentang } \\
\text { Pendidikan } \\
\text { Agama } \\
\text { Islammelakukan } \\
\text { sesauatu }\end{array}$ & Mahasiswa mengerjakan \\
\hline $\begin{array}{l}\text { Kegiatan akhir: } \\
\text { Dosen } \\
\text { menyimpulkan } \\
\text { pelajaran. }\end{array}$ & $\begin{array}{l}\text { Kegiatan akhir: } \\
\text { Sebagian mahasiswa mendengarkan }\end{array}$ \\
\hline $\begin{array}{l}\text { Dosen } \\
\text { menutup } \\
\text { pelajaran } \\
\text { dengan salam }\end{array}$ & Mahasiswa menjawab salam \\
\hline
\end{tabular}

Dari hasil pengamatan yang tergambar dalam tabel 3 dan tabel 4 dapat diambil kesimpulan bahwa dosen belum begitu baik dalam melaksanakan kegiatan pembelajaran. Dosen belum mampu menumbuhkan antusias dan keaktifan mahasiswa selama pembelajaran. Mahasiswa belum baik dalam mengikuti pembelajaran PAI dalam materi hakikat Agama. Hanya sebagian 
mahasiswa saja yang sudah menunjukkan keaktifan dan motivasi mereka selama mengikuti pelajaran.

Masih banyak mahasiswa membuat kegaduhan di dalam kelas, hanya beberapa mahasiswa saja yang terlihat memperhatikan dan serius ketika proses pembelajaran Pendidikan Agama Islamberlangsung. Pada saat pembelajaran Pendidikan Agama Islamsebelum menerapkan model kooperatif tipe jigsaw dengan menggunakan media vidio dr Zakir Naik hasil belajar mahasiswa masih rendah, hal ini dapat dilihat dari nilai hasil tes tulis mahasiswa. Berikut ini disajikan tabel hasil praktik Pendidikan Agama Islam sebelum menerapkan model kooperatif tipe jigsaw dengan menggunakan media vidio dr Zakir Naik pada mahasiswa Akuntansi.

\section{Siklus I}

\section{Persiapan dan Perencanaan}

Pertemuan pertama dilaksanakan pada hari senin tanggal 19 Maret 2018. Pembelajaran dimulai pukul 13.00. Pada siklus I ini peneliti membuat rancangan kegiatan pembelajaran Pendidikan Agama Islam menggunakan model kooperatif jigsaw melalui media vidio dr Zakir Naik bagi mahasiswa kelas Akuntansi 1.

\section{Tindakan}

Peneliti bertindak sebagai pengamat dan dosen yang mengajar. Dosen selalu memberikan motivasi kepada mahasiswa untuk selalu aktif dalam proses pembelajaran.

\section{Pengamatan}

Pelaksanaan penelitian tindakan kelas yang pertama dilaksanakan dengan mengamati perilaku mahasiswa. Peneliti memantau pembelajaran Pendidikan Agama Islam. Selain itu, peneliti mengamati mahasiswa sesuai dengan objek yang dilihatnya.

Hasil Pengamatan Aktivitas Mahasiswa dan Dosen dalam Meningkatkan Pembelajaran Pendidikan Agama IslamMelalui Penerapan Model Kooperatif Tipe Jigsaw dengan Menggunakan Media Vidio dr Zakir Naik Siklus I

\begin{tabular}{|l|l|}
\hline Jenis & Hasil Pengamatan \\
Permasalahan & \\
\hline
\end{tabular}




\begin{tabular}{|c|c|}
\hline $\begin{array}{l}\text { Aktivitas belajar } \\
\text { mahasiswa }\end{array}$ & $\begin{array}{l}\text { Aktivitas belajar sebagian mahasiswa belum cukup baik, } \\
\text { hal ini terlihat dari respon mahasiswa dalam } \\
\text { penerimaan materi, mahasiswa belum sepenuhnya } \\
\text { konsentrasi dalam penerimaannya, dan dosen harus } \\
\text { memberikan rangsangan positif yang lebih kepada } \\
\text { mahasiswa saat kegiatan pembelajaran Pendidikan } \\
\text { Agama Islamberlangsung tetapi sudah ada peningkatan } \\
\text { dengan sebelum menggunakan model kooperatif tipe } \\
\text { jigsaw melaui media vidio dr Zakir Naik. }\end{array}$ \\
\hline $\begin{array}{l}\text { Aktivitas } \\
\text { dosen }\end{array}$ & $\begin{array}{l}\text { Dosen dalam menjelaskan materi Pendidikan Agama } \\
\text { Islamkurang maksimal dikarenakan banyak waktu yang } \\
\text { tersita untuk mengkondisikan mahasiswa-mahasiswa } \\
\text { yang ramai sendiri. }\end{array}$ \\
\hline $\begin{array}{l}\text { Disiplin } \\
\text { mahasiswa }\end{array}$ & $\begin{array}{l}\text { Kedisiplinan mahasiswa masih belum maksimal. } \\
\text { Mahasiswa belum dapat menciptakan suasana } \\
\text { pembelajaran yang kondusif, meskipun bersemangat, } \\
\text { namun masih ada sebagian mahasiswa yang gaduh dan } \\
\text { berbicara sendiri dengan temannya. Selain itu, ada juga } \\
\text { yang masih jalan-jalan di dalam kelas saat ada kelompok } \\
\text { pada saat berdiskusi. }\end{array}$ \\
\hline $\begin{array}{ll}\text { Keaktifan } & \text { dan } \\
\text { percaya } & \text { diri } \\
\text { mahasiswa } & \end{array}$ & $\begin{array}{l}\text { Keaktifan dan percaya diri mahasiswa masih kurang } \\
\text { tampak, hal ini terlihat karena masih adanya mahasiswa } \\
\text { yang masih malu bertanya jika ada materi yang belum di } \\
\text { megerti }\end{array}$ \\
\hline
\end{tabular}

Hasil Pengamatan Penelitian Tindakan Kelas Siklus I Dosen dan Mahasiswa

\begin{tabular}{|l|l|}
\hline Dosen & Mahasiswa \\
\hline Kegiatan awal: & Kegiatan awal: \\
Dosen membuka & Mahasiswa menjawab salam dan menjelaskan kehadiran \\
pelajaran dengan & mahasiswa . \\
mengucapkan & \\
salam dan & \\
mempresensi & \\
mahasiswa. & \\
\hline $\begin{array}{l}\text { Dosen } \\
\text { menyampaikan }\end{array}$ & Sebagian mahasiswa mendengarkan tetapi ada yang \\
\hline
\end{tabular}




\begin{tabular}{|c|c|}
\hline $\begin{array}{l}\text { kompetensi dasar } \\
\text { dan } \\
\text { menyampaikan } \\
\text { tujuan } \\
\text { pembelajaran }\end{array}$ & \\
\hline $\begin{array}{l}\text { Dosen } \\
\text { melakukan } \\
\text { apersepsi dan } \\
\text { sekaligus } \\
\text { menjelaskan } \\
\text { prosedur } \\
\text { pembelajaran } \\
\text { menggunakan m } \\
\text { model kooperatif } \\
\text { tipe jigsaw } \\
\text { melaui media } \\
\text { vidio dr Zakir } \\
\text { Naik }\end{array}$ & $\begin{array}{l}\text { Sebagian mahasiswa mendengarkan tetapi ada yang } \\
\text { berbgicara sendiri }\end{array}$ \\
\hline $\begin{array}{l}\text { Kegiatan inti: } \\
\text { Dosen } \\
\text { menjelaskan } \\
\text { materi mengenai } \\
\text { Pendidikan } \\
\text { Agama } \\
\text { Islammelakukan } \\
\text { sesuatu. }\end{array}$ & $\begin{array}{l}\text { Kegiatan inti: } \\
\text { Mahasiswa mendengarkan penjelasan namun ada } \\
\text { beberapa mahasiswa yang masih terlihat ramai. }\end{array}$ \\
\hline \begin{tabular}{lr}
\multicolumn{2}{l}{ Dosen } \\
menerapkan \\
model kooperatif \\
tipe $\quad$ jigsaw \\
dengan & cara \\
membuat \\
kelompok asal \\
dan kelompok \\
ahli lalu & dosen \\
membagi vidio \\
dr Zakir & Naik
\end{tabular} & $\begin{array}{l}\text { Mahasiswa membentuk kelompok asal dan kelompok } \\
\text { ahli, mahasiswa berdiskusi di kelompok ahli } \\
\text { berdasarkan vidio dr Zakir Naik yang telah dibagikan } \\
\text { terhadap masing-masing kelompok ahli. }\end{array}$ \\
\hline
\end{tabular}




\begin{tabular}{|c|c|}
\hline $\begin{array}{l}\text { kepada masing- } \\
\text { masing } \\
\text { kelompok untuk } \\
\text { di diskusikan }\end{array}$ & \\
\hline $\begin{array}{l}\text { Dosen meminta } \\
\text { mahasiswa untuk } \\
\text { kembali asal dan } \\
\text { menjelaskan } \\
\text { materi yang telah } \\
\text { dididkusikan } \\
\text { kepada } \\
\text { temannya. }\end{array}$ & $\begin{array}{l}\text { Mahasiswa kembali ke kelompok asal dan } \\
\text { memperhatikan temannya pada saat menjelaskan materi } \\
\text { yang telah didiskusikan namun sebagian mahasiswa } \\
\text { masih merasa malu bertanya jika ada materi yang } \\
\text { belum mengerti. }\end{array}$ \\
\hline $\begin{array}{l}\text { Dosen } \\
\text { memberikan } \\
\text { tugas Pendidikan } \\
\text { Agama } \\
\text { Islammelakukan } \\
\text { sesuatu dengan } \\
\text { memperhatikan } \\
\text { vidio dr Zakir } \\
\text { Naik }\end{array}$ & $\begin{array}{l}\text { Mahasiswa mengerjakan tugas dari dosen dari vidio } \mathrm{dr} \\
\text { Zakir Naik yang diberikan dari dosen. }\end{array}$ \\
\hline $\begin{array}{l}\text { Kegiatan akhir: } \\
\text { Dosen } \\
\text { menyimpulkan } \\
\text { pelajaran. }\end{array}$ & $\begin{array}{l}\text { Kegiatan akhir: } \\
\text { Mahasiswa mendengarkan dengan baik }\end{array}$ \\
\hline $\begin{array}{l}\text { Dosen menutup } \\
\text { pelajaran dengan } \\
\text { salam }\end{array}$ & Mahasiswa menjawab salam \\
\hline
\end{tabular}

Kegiatan pembelajaran siklus I evaluasi diadakan ketika pembelajaran berlangsung. dalam aktivitas itu, mahasiswa Pendidikan Agama Islam melakukan suatu aktivitas hal itu mengukur kemampuan dan pemahaman Pendidikan Agama Islam..

\section{Refleksi}

Tahap refleksi pada siklus I untuk memperbaiki proses belajar mengajar materi Pendidikan Agama Islam melalui Penerapan Model Kooperatif Tipe 
Jigsaw dengan Menggunakan Media Vidio dr Zakir Naik siklus II. Tahap ini dilakukan peneliti guna melihat hambatan yang dialami dosen pada saat pelaksanaan siklus I. Hal yang akan direfleksikan adalah mencakup aktivitas dosen dan mahasiswa. Pada pelaksanaan siklus I, terdapat beberapa hambatan yang membuat kendala ketercapaian nilai Pendidikan Agama Islam menjadi kurang maksimal. Beberapa hambatan tersebut adalah:

1. Mahasiswa merasa sulit menerangkan kepada teman kelompoknya.

2. Mahasiswa masih merasa malu bertanya jika ada materi yang tidak dimengerti

3. Dosen kurang bisa membagi waktu pembelajaran

4. Dosen kurang memantau mahasiswa pada saat berdiskusi

Dari hambatan-hambatan yang muncul itulah akan dilakukan perbaikan untuk siklus selanjutnya. Perbaikan dilakukan dengan harapan pembelajaran akan mengalami peningkatan baik ketercapaian proses secara deskripsi yang dilakukan oleh dosen dan mahasiswa maupun ketercapaian keterampilan Pendidikan Agama Islam yang diukur menggunakan data-data nilai. Adapun upaya untuk mengatasi hambatan yang muncul di siklus I adalah sebagai berikut.

1. Dosen mulai menerangkan akan sistem pembelajaran secara jelas sebelum pembelajaran di mulai.

2. Dosen memberikan penjelasan agar mahasiswa mau menjelaskan materi dengan sungguh-sungguh kepada teman.

3. Dosen memberikan pengertian tidak perlu malu bertanya jikalau ada materi yang belum mengerti.

4. Dosen mulai mengatur waktu agar tidak terburu-buru dalam melaksanakan pembelajaran sehingga kegiatan mahasiswa dalam menulis dapat berjalan dengan lancar.

5. Dosen lebih banyak memantau kegiatan diskusi mahasiswa dan dosen mulai membuat pembelajaran sesuai dengan rencana.

\section{Siklus II.}

Pada siklus II, tindakan yang dilakukan hampir sama pada siklus I. Dosen hanya lebih mefokuskan pada hal-hal yang dirasa masih kurang pada siklus I untuk selanjutnya diperbaiki pada siklus II. Pada siklus II hambatan yang dialami dosen atau mahasiswa pada siklus I dapat diatasi. Langkah-langkah 
pembelajaran pada siklus I dapat diatasi. Berikut adalah pelaksanaan pembelajaran di kelas Akuntansi I siklus II.

\section{Persiapan dan Perencanaan}

Pelaksanaan penelitian tindakan kelas pada siklus II ini dilaksanakan untuk mengatasi beberapa hambatan yang ada pada siklus I. Peneliti pada tahap ini berupaya memadukan hasil refleksi siklus I agar siklus II lebih efektif dengan hasil yang maksimal. Selain itu, lebih mengoptimalkan waktu pembelajaran. Kegiatan PTK siklus II dilaksanakan pada hari senin tanggal 26 Maret 2018. Pembelajaran dimulai pukul 013.00 dengan materi pembelajaran yang lebih ditekankan pada aktivitas PAI dalam materi hakikat Agama.

Melihat pada siklus I aktivitas berbicara mahasiswa masih kurang, untuk itulah peneliti menambahkan langkah-langkah pembelajaran yang nantinya diharapkan dapat memberikan keberanian kepada mahasiswa untuk berdiskusi dalam materi hakikat Agama. Pelaksanaan penelitian tindakan kelas pada siklus II ini peneliti tetap membuat rancangan persiapan dosen, rancangan pelaksanaan kegiatan pembelajaran, dan rancangan penilaian kegiatan Pendidikan Agama Islammelalui penerapan model kooperatif tipe jigsaw dengan menggunakan media vidio dr Zakir Naik. Bahan dan alat yang digunakan dalam pembelajaran ini, yaitu berupa vidio dr Zakir Naik.

\section{Tindakan II}

Tindakan pada siklus II dilaksanakan dalam satu pertemuan yaitu pada hari senin tanggal 26 Maret 2018 selama 2X45 menit. Pada siklus II diikuti 45 mahasiswa sesuai dengan jumlah yanga ada pada siklus I.

Langkah-langkah pembelajaran pada siklus II adalah sebagai berikut.

Langkah I : Dosen membuka pelajaran dan menanyakan kehadiran mahasiswa.

Langkah II : Dosen mengkondisikan mahasiswa agar siap menerima pelajaran.

Langkah III : Dosen mulai menyampaikan kepada mahasiswa tentang hasil yang telah dicapai pada pertemuan sebelumnya. Mahasiswa yang mempunyai nilai tertinggi disampaikan supaya yang lain termotivasi agar lebih baik. Dosen menyampaikan kesalahankesalahan yang paling sering dilakakukan mahasiswa dalam diskusi materi hakikat Agama. 
Langakah IV : Sebelum menerapakan model kooperatif jigsaw melalui media vidio dr Zakir Naik, dosen terlebih dahulu menerangkan skema pembebelajaran dengan jelas supaya mahasiswa tidak bingung dalam pelaksanaan pembelajaran. Dosen memberikan kepada mahasiswa untuk bertanya jika belum jelas

Langkah V : Dosen menerapkan model kooperatif tipe jigsaw.

Langkah VI : Dosen membagi mahasiswa menjadi 4 kelompok dengan setiap kelompok terdiri 5 mahasiswa

Langkah VII : Kelompok (A, B, C, dan D) yang telah membentuk kemudian menentukan wakil untuk membentuk juru bicara.

Langkah VIII : Kelompok ahli mendalami topik yang terdapat pada vidio dr Zakir Naik, adapun topik yang terdapat pada vidio dr Zakir Naik tentang hakikat Agama

Langkah X : Dosen mengadakan evaluasi terhadap pembelajaran yang sudah dilkukan.

Langkah XI : Dosen menutup pelajaran.

\section{Pengamatan}

Secara keseluruhan aktivitas mahasiswa dan dosen dalam pembelajaran Pendidikan Agama Islam pada siklus II ini sudah mengalami peningkatan. Terlihat dengan suasana kelas waktu proses belajar mengajar sudah kondusif dan juga hidup dengan adanya keaktifan mahasiswa.

Rangkuman hasil pengamatan pada saat pembelajaran menerapkan model kooperatif tipe jigsaw dengan menggunakan media vidio dr Zakir Naik dalam pembelajaran menulis pada siklus II secara lengkap tercantum pada tabel berikut. Hasil Pengamatan Aktivitas Mahasiswa dan Dosen dalam Meningkatkan Pembelajaran Pendidikan Agama Islam melalui Penerapan Model Koopeatif Tipe Jigswaw dengan Menggunakan Media Vidio dr Zakir Naik Siklus II

\begin{tabular}{|l|l|}
\hline $\begin{array}{l}\text { Jenis } \\
\text { Permasalahan }\end{array}$ & Hasil Pengamatan \\
\hline $\begin{array}{l}\text { Aktivitas } \\
\text { Belajar }\end{array}$ & $\begin{array}{l}\text { Aktivitas belajar mahasiswa pada siklus ini sudah tampak } \\
\text { Mahasiswa }\end{array}$ \\
& $\begin{array}{l}\text { sertarik terhadap pembelajaran PAI dalam materi hakikat } \\
\text { Agama, hal ini terlihat dari kegiatan tanya jawab yang }\end{array}$ \\
& dilakukan antara mahasiswa dan dosen, dan juga praktik \\
& Pendidikan Agama Islamyang dilakukan masing-masing \\
\hline
\end{tabular}




\begin{tabular}{|l|l|}
\hline \multirow{2}{*}{ Aktivitas dosen } & $\begin{array}{l}\text { kelompok. Mahasiswa sudah mulai berani } \\
\text { mengungkapan pendapatnya pada saat berdiskusi baik } \\
\text { kelompok asal maupun kelompok ahli. }\end{array}$ \\
& $\begin{array}{l}\text { Dosen dalam menjelaskan materi Pendidikan Agama } \\
\text { Islammembuat sesuatu sudah cukup 1 lancar dan runtut. } \\
\text { Dosen cukup mampu mengkondisikan mahasiswa yang } \\
\text { berbicara sendiri dengan teman sebelahnya, karena } \\
\text { mahasiswa sudah dapat menciptakan suasana belajar } \\
\text { yang kondusif. Selain itu, dosen juga berusaha } \\
\text { membimbing mahasiswa pada saat diskusi dikelompok } \\
\text { ahli, apabila pada saat diskusi mengalami kesulitan. }\end{array}$ \\
\hline $\begin{array}{l}\text { Disiplin } \\
\text { mahasiswa }\end{array}$ & $\begin{array}{l}\text { Mahasiswa sudah dapat menciptakan suasana belajar } \\
\text { yang kondusif. Hal tersebut dapat dilihat ketika proses } \\
\text { pembelajaran berlangsung, mahasiswa yang berbicara } \\
\text { sendiri dan menganggu temannya sudah berkurang, } \\
\text { meskipun pada saat pembelajaran sesekali masih terlihat } \\
\text { mahasiswa ramai saat berdiskusi kelompok, bisa } \\
\text { dikendalikan oleh dosen dengan baik. }\end{array}$ \\
\hline $\begin{array}{l}\text { Keaktifan dan } \\
\text { percaya diri }\end{array}$ & $\begin{array}{l}\text { Keaktifan dan percaya diri mahasiswa sudah cukup baik, } \\
\text { hal ini tampak ketika mahasiswa sudah tidak merasa } \\
\text { malu lagi untuk bertanya jika ada materi yang belum atau } \\
\text { tidak dimengerti. Kegiatan ini bagi mahasiswa akan } \\
\text { menumbuhkan kepercayaan diri dan dapat melatih } \\
\text { mahasiswa dalam menlis petunjuk }\end{array}$ \\
\hline
\end{tabular}

Penelitian Tindakan Kelas pada siklus II ini cukup mengalami kemajuan dalam kegiatan pembelajaran PAI dalam materi hakikat Agama. Hal tersebut dapat dilihat dari tabel di atas, cukup mengalami kemajuan dibandingkan pada siklus I antara lain aktivitas belajar mahasiswa, faktor dari dosennya, disiplin mahasiswa, serta keaktifan dan percaya diri mahasiswa.

Hasil Pengamatan Penelitian Tindakan Kelas Siklus II dosen dan mahasiswa

\begin{tabular}{|l|l|}
\hline Dosen & Mahasiswa \\
\hline Kegiatan awal: & Kegiatan awal: \\
Dosen & Mahasiswa menjawab salam dan menjelaskan kehadiran \\
membuka & mahasiswa . \\
pelajaran & \\
\hline
\end{tabular}




\begin{tabular}{|c|c|}
\hline $\begin{array}{l}\text { dengan } \\
\text { mengucapkan } \\
\text { salam dan } \\
\text { mempresensi } \\
\text { mahasiswa. }\end{array}$ & \\
\hline $\begin{array}{l}\text { Dosen } \\
\text { menyampaikan } \\
\text { kompetensi } \\
\text { dasar dan } \\
\text { menyampaikan } \\
\text { tujuan } \\
\text { pembelajaran }\end{array}$ & $\begin{array}{l}\text { Sebagian mahasiswa mendengarkan tetapi ada yang } \\
\text { berbicara sendiri }\end{array}$ \\
\hline $\begin{array}{l}\text { Dosen mulai } \\
\text { menyampaikan } \\
\text { kepada } \\
\text { mahasiswa } \\
\text { tentang hasil } \\
\text { yang telah } \\
\text { dicapai pada } \\
\text { pertemuan } \\
\text { sebelumnya. }\end{array}$ & Sebagian mahasiswa mendengarkan dengan baik. \\
\hline $\begin{array}{l}\text { Dosen } \\
\text { melakukan } \\
\text { apersepsi dan } \\
\text { sekaligus } \\
\text { menjelaskan } \\
\text { prosedur } \\
\text { pembelajaran } \\
\text { menggunakan } \\
\text { m model } \\
\text { kooperatif tipe } \\
\text { jigsaw melaui } \\
\text { media vidio dr } \\
\text { Zakir Naik }\end{array}$ & $\begin{array}{l}\text { Sebagian mahasiswa mendengarkan tetapi ada yang } \\
\text { berbgicara sendiri }\end{array}$ \\
\hline $\begin{array}{l}\text { Sebelum } \\
\text { menerapakan }\end{array}$ & $\begin{array}{l}\text { Sebagian mahasiswa mendengarkan tetapi ada yang } \\
\text { berbgicara sendiri }\end{array}$ \\
\hline
\end{tabular}




\begin{tabular}{|l|l|}
\hline model & \\
kooperatif & \\
jigsaw melalui & \\
media vidio dr & \\
Zakir Naik, & \\
dosen terlebih & \\
dahulu & \\
menerangkan & \\
skema & \\
pembebelajaran & \\
dengan jelas & \\
supaya & \\
mahasiswa tidak & \\
bingung dalam & \\
pelaksanaan & \\
pembelajaran. & \\
Dosen & \\
memberikan & \\
kepada & \\
mahasiswa & \\
untuk bertanya & \\
jika belum jelas & \\
\hline Kegiatan inti: & Kegiatan inti: \\
Dosen & Mahasiswa mendengarkan penjelasan namun ada \\
menjelaskan & beberapa mahasiswa yang masih terlihat ramai. \\
materi & \\
mengenai & \\
Pendidikan & \\
Agama dengan & \\
Islammelakukan & \\
sesuatu. & \\
\hline $\begin{array}{l}\text { Dosen } \\
\text { menerapkan } \\
\text { model } \\
\text { kooperatif tipe } \\
\text { jigsaw masing-masing kelompok ahli. } \\
\text { cara membuat }\end{array}$ & \\
\hline
\end{tabular}




\begin{tabular}{|l|l|}
\hline kelompok asal & \\
dan kelompok & \\
ahli lalu dosen & \\
membagi vidio & \\
dr Zakir Naik & \\
kepada masing- & \\
masing & \\
kelompok di & \\
untuk & \\
diskusikan & \\
\hline $\begin{array}{l}\text { Dosen } \\
\text { berkeliling }\end{array}$ & Mahasiswa yang belum memahami bertanya kepada \\
untuk & dosen \\
memantau & \\
mahasiswa dan & \\
mengarahkan & \\
setiap tim jika & \\
mengalami & \\
kesulitan. & \\
\hline $\begin{array}{l}\text { Dosen meminta } \\
\text { mahasiswa }\end{array}$ & Mahasiswa kembali ke kelompok asal dan \\
untuk kembali & memperhatikan temannya pada saat menjelaskan materi \\
asal telah didiskusikan namun sebagian mahasiswa \\
menjelaskan \\
materi yang & masih merasa malu bertanya jika ada materi yang belum \\
telah mengerti . \\
dididkusikan & \\
kepada & \\
temannya. & \\
\hline $\begin{array}{l}\text { Dosen } \\
\text { memberikan } \\
\text { tugas } \\
\text { Pendidikan } \\
\text { Agama } \\
\text { Islammelakukan } \\
\text { sesuatu dengan } \\
\text { memperhatikan }\end{array}$ & \\
\hline
\end{tabular}




\begin{tabular}{|l|l|}
\hline $\begin{array}{l}\text { vidio dr Zakir } \\
\text { Naik }\end{array}$ & \\
\hline $\begin{array}{l}\text { Kegiatan akhir: } \\
\text { Dosen } \\
\text { menyimpulkan } \\
\text { pelajaran. }\end{array}$ & $\begin{array}{l}\text { Kegiatan akhir: } \\
\text { Mahasiswa mendengarkan dengan baik }\end{array}$ \\
\hline $\begin{array}{l}\text { Dosen } \\
\text { menutup } \\
\text { pelajaran } \\
\text { dengan salam }\end{array}$ & Mahasiswa menjawab salam \\
\hline
\end{tabular}

Kegiatan pembelajaran siklus II evaluasi diadakan ketika pembelajaran berlangsung. dalam aktivitas itu, mahasiswa berlatih untuk berimprovisasi bermain peran. Aktivitas itu baik untuk mengukur kemampuan berbicara mahasiswa..

\section{Refleksi}

Refleksi guna memperbaiki hambatan-hambatan pada siklus I yang telah diterapkan pada siklus II, ternyata memberikan hasil yang meningkat baik dilihat dari aktivitas dosen dan mahasiswa. Sesuai lembar pengamatan aktivitas dosen dan mahasiswa, dan lembar observasi terhadap aktivitas timbal balik antara dosen dan mahasiswa pada saat berlangsungnya pembelajaran menunjukkan bahwa dosen telah mampu mengendalikan kelas serta mahasiswa mampu merespon bimbingan dari dosen dengan lebih baik.

\section{Siklus III}

\section{Persiapan dan Perencanaan}

Pertemuan pertama dilaksanakan pada hari senin tanggal 02 April 2018. Pembelajaran dimulai pukul 013.00. Pada siklus III ini peneliti membuat rancangan kegiatan pembelajaran Pendidikan Agama Islam melalui penerapan model kooperatif jigsaw dengan menggunakan media vidio dr Zakir Naik dan media audio visual bagi mahasiswa.

\section{Tindakan}


Peneliti bertindak sebagai pengamat dan dosen bertindak sebagai pengajar. Dosen selalu memberikan motivasi kepada mahasiswa untuk selalu aktif dalam proses pembelajaran. Langkah-langkah pembelajaran sama dengan siklus II Pengamatan.

Pelaksanaan penelitian tindakan kelas yang pertama dilaksanakan dengan mengamati perilaku mahasiswa. Peneliti memantau pembelajaran Pendidikan Agama Islam. Selain itu, peneliti mengamati mahasiswa sesuai dengan objek yang dilihatnya.

Pembelajaran Pendidikan Agama Islam melalui penerapan model koopeartif tipe jigsaw dengan menggunakan media vidio dr Zakir Naik pada siklus I dan II belum sepenuhnya merubah kondisi kelas menjadi kondusif karena mahasiswa masih ramai sendiri tetapi dengan menerapkan model koopeartif tipe jigsaw dengan menggunakan media vidio dr Zakir Naik membuat mahasiswa termotivasi untuk memperhatikan dosen dalam berdiskusi materi Pendidikan Agama Islamu. Dari pihak dosen juga belum sepenuhnya memperhatikan mahasiswa atau kelompok pada saat berdiskusi, dosen lebih fokus pada beberapa kelompok. Dosen hanya sesekali mengkondisikan kelompok yang masih terlihat ramai. Hasil Pengamatan Aktivitas Mahasiswa dan Dosen dalam Meningkatkan Pembelajaran Pendidikan Agama Islam melalui Penerapan Model Kooperatif Tipe Jigsaw dengan Menggunakan Media Vidio dr Zakir Naik Siklus I

\begin{tabular}{|l|l|}
\hline $\begin{array}{l}\text { Jenis } \\
\text { Permasalahan }\end{array}$ & Hasil Pengamatan \\
\hline $\begin{array}{l}\text { Aktivitas belajar } \\
\text { mahasiswa }\end{array}$ & $\begin{array}{l}\text { Aktivitas belajar sebagian mahasiswa cukup baik, hal ini } \\
\text { terlihat dari respon mahasiswa dalam penerimaan materi, } \\
\text { mahasiswa sudah sepenuhnya konsentrasi dalam } \\
\text { penerimaannya, dan dosen telah memberikan rangsangan } \\
\text { positif yang lebih kepada mahasiswa saat kegiatan } \\
\text { pembelajaran Pendidikan Agama Islamberlangsung. }\end{array}$ \\
\hline $\begin{array}{l}\text { Aktivitas dari } \\
\text { dosen }\end{array}$ & $\begin{array}{l}\text { Dosen dalam menjelaskan materi Pendidikan Agama } \\
\text { Islamsudah maksimal. } \\
\text { Disiplin }\end{array}$ \\
$\begin{array}{l}\text { Kedisiplinan mahasiswa sudah maksimal. Mahasiswa } \\
\text { menciptakan suasana pembelajaran yang kondusif, } \\
\text { bersemangat, dan sebagian mahasiswa yang gaduh dan } \\
\text { berbicara sendiri dengan temannya sudah tidak ada. }\end{array}$ \\
\hline
\end{tabular}




\begin{tabular}{|lr|l|}
\hline & & Selain itu mahasiswa berdiskusi dengan semangat. \\
\hline Keaktifan dan & $\begin{array}{l}\text { Keaktifan dan percaya diri mahasiswa mulai terlihat, hal } \\
\text { percaya } \\
\text { mahasiswa }\end{array}$ & diri \\
& & $\begin{array}{l}\text { ini terlihat dari kemauan mahasiswa belajar aktif dan } \\
\text { menanyakan beberapa hal mengenai pembuatan } \\
\text { petunjuk. }\end{array}$ \\
\hline
\end{tabular}

Hasil Pengamatan Penelitian Tindakan Kelas Siklus III Dosen dan Mahasiswa

\begin{tabular}{|l|l|}
\hline Dosen & Mahasiswa \\
\hline $\begin{array}{l}\text { Kegiatan awal: } \\
\text { Dosen membuka } \\
\text { pelajaran dengan } \\
\text { mengucapkan salam } \\
\text { dan mempresensi } \\
\text { mahasiswa. }\end{array}$ & Kegiatan awal: \\
mahasiswa . \\
\hline $\begin{array}{l}\text { Dosen menjawab salam dan menjelaskan kehadiran } \\
\text { menyampaikan } \\
\text { kompetensi dasar } \\
\text { dan menyampaikan } \\
\text { tujuan pembelajaran }\end{array}$ & \\
\hline $\begin{array}{l}\text { Dosen melakukan } \\
\text { apersepsi dan } \\
\text { sekaligus } \\
\text { menjelaskan } \\
\text { prosedur } \\
\text { pembelajaran } \\
\text { menggunakan mahasiswa mendengarkan dengan baik } \\
\text { model kooperatif } \\
\text { tipe jigsaw melaui } \\
\text { media vidio dr Zakir } \\
\text { Naik }\end{array}$ & \\
\hline $\begin{array}{l}\text { Kegiatan inti: } \\
\text { Dosen menjelaskan } \\
\text { materi mengenai } \\
\text { Pendidikan Agama }\end{array}$ & \\
$\begin{array}{l}\text { Islammelakukan } \\
\text { sesuatu. }\end{array}$ & \\
\hline Dosen menerapkan & Mahasiswa mendengarkan penjelasan dengan antusias. \\
\hline
\end{tabular}




\begin{tabular}{|c|c|}
\hline $\begin{array}{l}\text { model } \\
\text { tipe jigsaw dengan } \\
\text { cara } \\
\text { kelompok asal dan } \\
\text { kelompok ahli lalu } \\
\text { dosen } \\
\text { vidio dr } \\
\text { kepada } \\
\text { masing Naik } \\
\text { untuk di diskusikan }\end{array}$ & $\begin{array}{l}\text { ahli, mahasiswa berdiskusi di kelompok ahli } \\
\text { berdasarkan vidio dr Zakir Naik yang telah dibagikan } \\
\text { terhadap masing-masing kelompok ahli. }\end{array}$ \\
\hline $\begin{array}{l}\text { Dosen meminta } \\
\text { mahasiswa untuk } \\
\text { kembali asal dan } \\
\text { menjelaskan materi } \\
\text { yang telah } \\
\text { dididkusikan kepada } \\
\text { temannya. }\end{array}$ & $\begin{array}{l}\text { Mahasiswa kembali ke kelompok asal dan } \\
\text { memperhatikan temannya pada saat menjelaskan materi } \\
\text { yang telah didiskusikan namun sebagian mahasiswa } \\
\text { masih merasa malu bertanya jika ada materi yang } \\
\text { belum mengerti. }\end{array}$ \\
\hline $\begin{array}{l}\text { Dosen memberikan } \\
\text { tugas Pendidikan } \\
\text { Agama } \\
\text { Islammelakukan } \\
\text { sesuatu dengan } \\
\text { memperhatikan } \\
\text { vidio dr Zakir Naik }\end{array}$ & $\begin{array}{l}\text { Mahasiswa mengerjakan tugas dari dosen dari vidio dr } \\
\text { Zakir Naik yang diberikan dari dosen. }\end{array}$ \\
\hline $\begin{array}{l}\text { Kegiatan akhir: } \\
\text { Dosen } \\
\text { menyimpulkan } \\
\text { pelajaran. }\end{array}$ & $\begin{array}{l}\text { Kegiatan akhir: } \\
\text { Mahasiswa mendengarkan dengan baik }\end{array}$ \\
\hline $\begin{array}{lr}\text { Dosen menutup } \\
\text { pelajaran } \\
\text { salam }\end{array}$ & Mahasiswa menjawab salam \\
\hline
\end{tabular}

Kegiatan pembelajaran siklus III evaluasi diadakan ketika pembelajaran berlangsung. dalam aktivitas itu, mahasiswa Pendidikan Agama Islammelakukan sesuatu. Aktivitas itu tidak saja baik untuk mengukur kemampuan Pendidikan Agama Islam, melainkan juga sebagai latihan PAI dalam materi hakikat Agama. 


\section{Refleksi}

Tahap refleksi pada siklus III untuk memperbaiki proses belajar mengajar materi Pendidikan Agama Islammelalui penerapan model kooperatif tipe jigsaw dengan menggunakan media vidio dr Zakir Naik pada proses pembelajaran. Tahap ini dilakukan antara dosen dan peneliti guna melihat hambatan yang dialami dosen pada saat pelaksanaan siklus III. Hal yang akan direfleksikan adalah mencakup aktivitas dosen dan mahasiswa serta perlengkapan menulis. Pada pelaksanaan siklus III, terdapat beberapa hambatan yang membuat kendala ketercapaian nilai Pendidikan Agama Islam menjadi kurang maksimal. Beberapa hambatan tersebut adalah:

1. Mahasiswa belum maksimal menggunakan waktu diskusi

2. Dosen kurang memantau mahasiswa pada saat berdiskusi

Perbaikan dilakukan dengan harapan pembelajaran akan mengalami peningkatan baik ketercapaian proses secara deskripsi yang dilakukan oleh dosen dan mahasiswa maupun ketercapaian keterampilan Pendidikan Agama Islam yang diukur menggunakan data-data nilai. Adapun upaya untuk mengatasi hambatan yang muncul di siklus III adalah sebagai berikut.

1. Dosen mulai menerangkan akan sistem pembelajaran secara jelas sebelum pembelajaran di mulai.

2. Dosen memberikan penjelasan agar mahasiswa mau menjelaskan materi dengan sungguh-sungguh kepada teman.

3. Dosen mulai mengatur waktu agar tidak terburu-buru dalam melaksanakan pembelajaran sehingga kegiatan mahasiswa dalam menulis dapat berjalan dengan lancar.

4. Dosen lebih banyak memantau kegiatan diskusi mahasiswa dan dosen mulai membuat pembelajaran sesuai dengan rencana.

\section{Penutup}

Berdasarkan pembahasan yang dilakukan dalam pembahasan sebelumnya tentang "Peningkatan Proses Pembelajaran Pendidikan Agama Islam Melalui Penerapan Model Kooperatif Tipe Jigsaw Dengan Menggunakan Media video dr. Zakir naik di Kelas Akuntasi STIE Sakti Alam Kerinci Sungai Penuh Semester Genapl Tahun 2017/2018”, maka dapat ditarik kesimpulan :

Peningkatan pelaksanaan proses pembelajaran Pendidikan Agama Islam sebelum menggunakan model kooperatif tipe jigsaw melalui media vidio dr 
Zakir Naik kurang optimal, terlihat mahasiswa yang masih ramai sendiri dan sulit untuk dikondisikan, hal ini membuat perhatian mahasiswa berkurang pada materi yang diajarkan. Proses pembelajaran pada siklus satu menjadi lebih menyenangkan dari sebelumnya karena mahasiswa mendapatkan pengalaman baru, dengan adanya kegaiatan tersebut. Mahasiswa yang dulu kurang aktif menjadi aktif selama pembelajaran, antusuias mahasiswa terlihat ketika berdiskusi. Namun dalam siklus satu ini masih terdapat hambatan-hambatan, hambatan-hambatan yang terjadi pada siklus I adalah antara lain (a) mahasiswa yang belum paham tentang langkah-langkah pembelajaran, (b) mahasiswa masih merasa malu untuk bertanya jika ada yang belum mengerti, dan (c) dosen kurang bisa membagi waktu pembelajaran, dosen kurang memantau mahasiswa pada saat berdiskusi. Upaya untuk mengatasi hambatan yang terjadi pada siklus antara lain (a) dosen menerangkan sistem pembelajaran secara jelas sebelum memulai pembelajaran, (b) dosen mulai mengatur waktu agar tidak terburu-buru dalam melaksanakan pembelajaran sehingga mahasiswa dalam berdiskusi dapat berjalan dengan lancar, dan (c) dosen lebih banyak memantau kegiatan mahasiswa dan dosen mulai membuat pembelajaran sesuai dengan rencana. Peningkatan proses pelaksanaan pembelajaran dalam siklus dua mengalami peningkatan, peningkatan tersebut terlihat ketika mahasiswa sudah bisa menerangkan materi yang telah dikuasainya kepada teman lain. Dalam mengerjakan tugas yang diberikan, mahasiswa sudah tidak mengalami kebingungan lagi.

Peningkatan proses pembelajaran berpengaruh terhadap hasil belajar mahasiswa. Penilaian hasil belajar mahasiswa dilihat penilain penampilan dalam diskusi dan tes tulis yang diberikan. Hasil penilaian diskusi dan dari tes tulis menggunakan model kooperatif tipe jigsaw melalui media vidio dr Zakir Naik menunjukan adanya peningkatan hasil.

\section{Bibliografi}

Abd, Rahman Assegaf, Studi Islam Kontektual Elaborasi Paradigma Baru Muslim Kaffah. Yogyakarta: Gama Media, 2005.

Azyumardi Azra., dkk., Buku Teks Pendidikan Agama Islam pada Perguruan

Tinggi Umum. Direktorat Perguruan Tinggi Agama Islam, Jakarta, 2002.

Sugiyono, Metode Penelitian Pendidikan Pendekatan Kuantitatif, Kualitatif dan R\&B, Bandung: Sinar Baru, 2010. 
Sugiyono, Metode Penelitian Pendidikan Pendekatan Kuantitatif, Kualitatif dan R\&B, Bandung: Sinar Baru, 2008

Suharsimi Arikunto, Prosedur Penelitian, Suatu Pendekatan Praktek, Jakarta: Rineka Cipta, 2002.

Kunandar, Langkah Mudah Penelitian Tindakan Kelas Sebagai Pengembangan Profesi Guru, Jakarta: Raja Grafindo Persada, 2008.

Sapardi, Penelitian Tindakan Kelas, Jakarta: Alfabeta, 2006.

Tritanto, Mendesain Model Pembelajaran Inovatif-Progresif, Jakarta: Kencana, 2010. 
102 | Belajea : Jurnal Pendidikan Islam, Vol. 4, No. 01, 2019

HALAMAN INI SENGAJA DIKOSONGKAN 